\title{
Innovation Beyond Borders: On Alternative Feminist Discourses of Innovation
}

\author{
Karin Berglund ${ }^{1 *}$, Katarina Pettersson ${ }^{2}$
}

Published: September 1, 2021

\begin{abstract}
In this article a feminist intervention is undertaken to mobilise alternative innovation discourses that recognise activity and passivity as enmeshed - as 'pactive'. Activity is found to perpetuate the mainstream innovation discourse, aligned with a male construct of an active and rational being. Thus, passivity is viewed as a concept that helps problematise, analyse, negotiate and transgress the discursive borders of innovation. The study is empirically driven from ethnographic insights that emerged in two research projects conducted in Sweden over four years, comprising 50 interviews. For the purpose of this article four cases are selected as they provide strong examples of how slowness is affirmed and integrated in everyday practices of innovation where activity and passivity are entwined. To mobilise alternative feminist discourses of innovation we take inspiration from philosopher Jonna Bornemark's concept of pactivity (a combination of activity and passivity) and Sara Ahmed's discussion of emotions, where passivity is related to passion and openness. Applying these two lenses to the empirical cases, aspects of pactivity are analysed and four alternative discourses of innovation are mobilised, making it possible to envision innovation as a social process where people stand in relation to their non-knowing, have space to be both passive and passionate and thus are open for enactment.
\end{abstract}

Keywords: innovation, feminist interrogation, passivity, activity, pactivity, innovation discourse

\section{INTRODUCTION}

Some years ago, the then Director General of the Swedish Governmental Agency for Innovation Systems proposed that 'If we want to be innovative, we have to affirm the world is increasingly changing,' concluding that 'we live in a world that is changing faster and faster.' Metaphorically, doing innovation was compared with 'having a huge wave to surf, while she underlined that 'if you lie down, not wanting to see this wave, you will be washed away.' What appears to underpin the discourse of innovation, expressed here, is activity. And perhaps certain kinds of activities - standing strong on an open sea and mastering nature - requiring characteristics such as strength, capability, self-reliance and courage. If you stop surfing the wave (being constantly active) you will be washed away, in the worst case towards an inevitable death. Symbolically, this implies that the innovation discourse provides little space for other calmer activities including contemplation, relaxation and recuperation.

At the heart of the research discourse on innovation, monotonous activity consisting of a search for innovation and a faith in its goodness, like that of a perpetual machine, has been identified (Segercrantz, Sveiby and Berglund, 2017). This 'self-reinforcing circle' (Segercrantz, Sveiby and Berglund, 2017: 277) propels innovation as something highly sought after and is seldom scrutinised. The desirable and unassailable outcomes of innovation and its capacity to bring about newness and sustain economic growth are highlighted in policy, research and everyday life (Sveiby, Gripenberg and Segercrantz, 2012). Ironically, however, through the emphasis on change, renewal and transformation, innovation discourses nevertheless appear to perpetuate taken-for-granted assumptions about gender. At face value, innovation discourses present objects and subjects as gender neutral. This is despite extant research showing that innovation is a gender-biased phenomenon (Alsos, Ljunggren and Hytti, 2013) that sustains gender structures in organisations (Andersson et al., 2012) and reproduces hetero-patriarchal relations and practices (Pecis, 2016), through perpetuating a male norm of innovation (Pettersson, 2007).

\footnotetext{
1 Professor of Business, Specialising in Entrepreneurship, at Stockholm Business School, Stockholm University, SWEDEN 
Hence, innovation discourse has been found to be gender blind (Andersson et al., 2012), preserve masculine practices (Wikhamn and Knights, 2013), and prioritise men, male-dominated networks and male-dominated sectors in policy incentives (Pecis and Priola, 2019; Pettersson, 2007). In contrast, women have been less likely to be granted the status of innovators (Berglund and Granat Thorslund, 2012). Their contributions have often been neglected (Blake and Hanson, 2005), and historical female inventors have been blatantly made invisible (Pecis and Berglund, 2021). Feminist engagements with innovation have certainly challenged the gendered innovation discourse. The strong links between innovation and technology are problematised when innovation is alternatively conceptualised as a subtle, incremental and iterative social process (Alsos, Ljunggren and Hytti, 2013), in which every wo/man should be able to take equal part (Andersson et al., 2012; Pecis, 2016; Pettersson, 2007). Research has found feminist resistance in various forms - including separatism - towards the 'masculinist' innovation discourse (Pettersson and Lindberg, 2013). Further, innovation can be seen as a feminist practice, because applying a feminist epistemology can evoke 'friction' and thus innovative and transformative power (Schiebinger and Schraudner, 2011; Berglund and Granat Thorslund, 2012; McIntyre, 2015).

In this article our purpose is to engage in a feminist interrogation of innovation as activity, that in the mainstream innovation discourse is aligned with a male construct of an active and rational being. Since activity is at the centre of the mainstream innovation discourse, we view its opposite - passivity - as a battering ram and thus a concept that can help to problematise, analyse and negotiate the borders of innovation. Empirically, we are inspired by rural men and women's stories of innovation, which emphasise the practice of slowing down and taking the time to 'stop and watch the sky'. The study is thus empirically driven, drawing from ethnographic insights that emerged in two research projects in Sweden conducted over four years, and comprising 50 interviews. We view this empirical material as providing powerful stories that provide examples of innovation (Siggeklow, 2007) located at the margins of the innovation discourse. These stories help us engage in a feminist analysis of innovation as an everyday, mundane activity where activity and passivity are entwined. The empirical insights also guided us to philosopher Jonna Bornemark and feminist scholar Sara Ahmed, who provide thought-provoking concepts. Bornemark's $(2018$; 2020) concept of reflexive 'intellectus' guides us to understand that, in practice, there is no pure activity or passivity, but we must understand the two as combined as 'pactivity'. In Ahmed's (2014) discussion on emotions, passivity is related to passion and openness. Applying these two lenses to the empirical stories, we shed light on the enmeshment of activity and passivity (pactivity) in innovative practices of men and women in rural areas.

Adopting a discursive approach to innovation, we view language as performative, generating effects that set borders for what is possible to say, and do, and how we can (re-) think a phenomenon. This means that our knowledge claim is related to phronesis (practical wisdom), rather than to episteme (scientific knowledge) or techne (know how) (Flyvbjerg, Landman and Schram, 2012). Metaphors help to facilitate such knowledge claims. We will return to the metaphors of surfing (activity) and stop and watch the sky (slowness) throughout the paper to highlight how borders of the innovation discourse can be transgressed. A phronetic approach to knowledge adds a 'bottom up' perspective that can tilt the status quo of something; in our case, innovation discourse. We view tilting the status quo as being at the heart of feminist interrogation, with its ambition to call scientific norms and androcentric rationalisations into question and challenge established ways of knowing (Harding, 1991). In our view this contributes to a transformative research agenda (Bell et al., 2020).

\section{TOWARDS A 'PACTIVE’ UNDERSTANDING OF INNOVATION}

To assist us in our feminist interrogation of innovation we turned to two inspiring women thinkers: philosopher Jonna Bornemark and feminist scholar Sara Ahmed. Both Bornemark and Ahmed discuss the constructions of dualisms - ratio/intellectus and I/Other. Their discussions link to a larger scheme of gendered binary constructions of activity/passivity. The constructions of ratio/intellectus, I/Other and activity/passivity set borders, but where there is a border there is also a meeting point. At the border, that and those unreflectively looked upon as innovation/innovators, can be questioned and transgressed. Through combining their respective thinking on passivity, as enmeshed with activity, it can be re-thought as pactivity, which helps us to unfold alternative innovation discourses.

\section{Jonna Bornemark on ratio, intellectus and 'pactivity'}

In order to understand activity in the conventional innovation discourse we are captivated by Bornemark's (2018) philosophical investigation of our current thought system. Taking inspiration from (pre-)renaissance philosophers, she describes how what she terms calculating 'ratio' practices, have taken precedence over 'intellectus' practices. Ratio describes an (economic) ratio(nality) where everything is turned into abstractions and generalisation in a search for strategies and answers. 
In contrast, intellectus represents the subjective, emotional and temporary, and stresses the human ability to 'not know', but to learn to cope with insecurity, instability, anxiety, confusion and chaos. In this representation, ratio/intellectus overlaps the reason/emotion binary and the rational 'ratio' is placed in relation to the 'emotional' intellectus. Of particular interest is how Bornemark argues that 'ratio' - the calculating mode of being - has gained the upper hand in contemporary society. This makes intellectus, with its ability to reflect upon our experiences, develop judgement and take responsibility - for example, injustices - as they unfold in everyday life, the underdog. We believe that ratio echoes strongly in the conventional innovation discourse's focus on activity.

However, Bornemark argues that ratio and intellectus should be seen as interdependent. Thus, both kinds of practices are needed. Without ratio - and its ability to represent 'truth' and 'the bigger picture' - it is difficult to navigate the complex terrain of contemporary society. Generalisations - in both numerical and textual form facilitate our common understandings of the world. But, without an ability to also practise intellectus, ratio can have a (dead)locking effect. A person might therefore follow instructions and general guidelines, which is what ratio practices demands. This, however, causes them to suffer from their inability to exercise judgement and to act 'in the heat of the moment'.

Practising intellectus, we propose, can be seen as a thoughtful activity; it implies acting as a judicious person, adapting to the specificities of a situation, accepting non-knowing of the outcome of that situation, without being confined to passivity. At the same time, the intellectus-driven human, who takes her time to nurture interpersonal qualities of love, empathy, friendship and care, may be seen as passive in her contemplation. This, in turn, puts the person at risk of being blamed for inappropriate slowness, according to contemporary discourses on efficiency and activity, which are incorporated in conventional discourses on innovation (and entrepreneurship).

At the heart of intellectus is the ability to stand in relation to 'non-knowing' and to endure such situations whereby human judgement can unfold. Bornemark (2020) views intellectus-driven activity as neither active (someone in full control on a surfboard), nor passive (a billiard ball that is struck on the table). Instead, she invents the concept 'pactive', arguing that in human action, there is no such thing as pure activity or pure passivity. In her elaboration of 'paction' she relates to the experience of giving birth. A woman giving birth must actively push, but also passively wait for labour pains (and the midwife who is helping her). Thus, it is through passivity that activity can be born. The two practices are deeply enmeshed, and separating them provides us with a discourse with only a one-sided dimension.

Actively and continuously riding the wave of innovation appears to be a practice strongly underpinned by ratio, detached from intellectus. Metaphorically speaking, the surfer is chasing the solution - or newness - but can never stop to actually enjoy it, because, as soon as the innovation has an impact on the world, the next thing must be invented. There is a continuous activity of doing - an activity where intellectus suffers. Slowing down and reflecting upon what a particular newness brings, or if it is the most important newness to chase, requires one to contemplate the surfing conditions on the beach. This 'pactivity' would describe what the stories of the rural women and men inform us about. They seem to accept non-knowing without being paralysed. Rather, they enact pactivity as part of their practices and lives.

\section{Sara Ahmed on emotions as performative}

The 'affective turn' has brought about a shift in social science to recognise feelings, and engage more critically in analytical, feminist, philosophical and political discussions on the role of emotions (e.g., Pedwell and Whitehead, 2012). This 'turn' has, however, (not yet) reached innovation research. In stating this, we do not mean that emotions are not important in innovation. On the contrary, we would like to point to how innovators' language may indeed be very emotional, but that they are conventionally described with a 'cool' distance, like, for example, picturing someone able to refrain from emotional turbulence on her ride on the surfboard.

In The Cultural Politics of Emotion, Ahmed (2014: 8) elucidates emotions as relations to oneself and others. In her view, emotions 'involve (re)actions of relations of "towardness' or "awayness" in relation to particular objects'. Here, emotions are seen as performative and contingent with sociality, since they are part of the very production of borders between subject and object (p. 6). Hence, expressions of emotions do things. For instance, the expression 'you make me sad' produces an agentic subject, with a capacity to transfer the object of sadness and plunge the other subject into a passive state. For Ahmed, the point is not to understand what is 'inside' a person. Rather, emotions shape the boundaries between you and I, or they and we, as well as becoming the building blocks of subjectivity. Emotions can therefore be seen as means through which both unity/division, or superiority/inferiority, are constructed.

Constructing the active innovator, who has often been described as a 'cool', 'hard', 'brave', 'fast', and 'quick' man in research, policy and practice (see Berglund and Granat Thorslund, 2012; Pettersson, 2007) creates a certain emotional state. This imaginary subject takes shape against the background of the passive Other who is sitting on the beach, perhaps pondering whether she too wants to ride the waves. She who, in contrast, is described as 'not yet there', 'cautious', and 'careful' (see Berglund and Granat Thorslund, 2012; Pettersson, 2007) which evoke 
another emotional state. It is in this way that emotions discursively contribute to the construction of particular subjectivities; the active innovator takes shape in relation to the passive Other. Ahmed's work is therefore especially useful in relation to understanding activity since it allows us to study how borders are invoked through the innovation discourse that produces the active innovator in contrast to the passive follower.

What is interesting when scrutinising activity and passivity is that passion and passive share the same root in the Latin word ('passio') for 'suffering', which is noticed by Ahmed (2014: 2-3):

To be passive is to be enacted upon, as a negation that is already felt as suffering. The fear of passivity is tied to the fear of emotionality, in which weakness is defined in terms of a tendency to be shaped by others. Softness is narrated as a proneness to injury. The association between passion and passivity is instructive. It works as a reminder of how 'emotion' has been viewed as 'beneath' the faculties of thought and reason. To be emotional is to have one's judgement affected: it is to be reactive rather than active, dependent rather than autonomous.

We understand her elaboration of passio(n) as follows: when a person becomes passionate $\mathrm{s} /$ he may run the risk of being 'taken over' by emotions, since as soon as one is taken over, one is purportedly no longer in control of one's feelings; instead, one can be enacted upon, which simultaneously aligns the subject with openness. Ahmed links such openness to the feminised body; a body that may be(come) 'penetrated' or 'invaded' by others, which makes it weak and vulnerable. Being enacted upon, metaphorically, paints a contrasting figure to the focused surfer - the innovator - who must stay on the board, leaving everything and everyone outside of the spotlight. Passivity, in relation to the male construct of an innovator as active, thereby becomes something to be feared, as it is bound with uncontrolled emotionality, implying one runs the risk of being shaped by others.

Innovation as a solitary surfing activity, however, sits in stark contrast to recent understandings of innovation as socially constituted (Styhre, 2013; Pecis, 2016) which depict a subtle, incremental and iterative learning process (Alsos, Ljunggren and Hytti, 2013, Andersson et al., 2012). In these understandings of innovation, we are inevitably enacted upon, because humans are social creatures. The logic here seems to be that the more enacted upon we can tolerate being, the more susceptible we become to our environment. We are thus prone to noticing where something needs to be fixed, or where 'newness' is needed. If such enactment leaves us no peace, we may engage in an innovative practice, in which we pay attention to how existing 'pieces' (ideas, materials, knowledge etc.) can be joined together in a new and innovative way.

When innovators are described as passionate they are opened up to external influence and to a kind of 'suffering'; suffering in terms of being enacted upon and having to see, and not avoiding taking in life and its realities; suffering in terms of wanting to fix what one has seen. Innovation, in this reading, is aligned with being open to external influence, being enacted upon, being responsive 'in the heat of the moment', which ties in neatly with Bornemark's understanding of intellectus.

\section{ON METHOD}

Inspired by Swedish rural men's and women's stories of innovation, which emphasise the practice of slowing down and taking the time to 'stop and watch the sky', our ambition in this paper is to unfold alternative discourses of innovation. Methodologically, we understand language as performative (Butler, 2011) and view the stories told not as stories 'against' innovation, but as a 'series of escapes, of small slides, of plays, of crossings, of flights' (Davies and Gannon, 2005, p. 313) that can evoke new discourses of innovation. In that sense, we seek to 'trouble' gender binaries (Butler, 2011) through telling an alternative narrative of innovation (Pettersson and Lindberg, 2013).

In the article we draw on interviews from two research projects in which we have previously been involved. One on women's entrepreneurship in rural Sweden, was undertaken in 2016 to 2020 and involved both authors. The other project on green care farming in Sweden, was undertaken in 2016 to 2020 and involved the second author. Our previous analyses of these interviews indicated that men and women developed new endeavours and ways of working in their rural businesses - sometimes in unconventional ways - and often stressing 'slowness' as important to everyday practices. We view this as an opportunity to better understand - and problematise innovation from a pactive point of view. In this way, the article is empirically driven, whilst aiming for conceptual and theoretical development.

The empirical material in both projects consist of a total of 50 interviews (project on women's entrepreneurship $\mathrm{N}=30$; project on green care farming $\mathrm{N}=20$ ). What was crucial in the selection of these interviews was not whether the stories told contained innovation, because many did in some way or another. Rather, our selection was guided by our aspiration to show the variation the narratives of innovation took, not only concerning the participants' businesses and ideas, but also regarding how the talked about their relation to non-knowing, passion and pactivity. 
Feminist Encounters: A Journal of Critical Studies in Culture and Politics, 5(2), 22

Table 1. Method

\begin{tabular}{lllll}
\hline & Tea & Maya & Beata & Johanna \\
\hline $\begin{array}{l}\text { Study/ } \\
\text { Year }\end{array}$ & $\begin{array}{l}\text { Rural women's } \\
\text { entrepreneurship }\end{array}$ & Rural women's & Rural women's \\
entrepreneurship & 2018 & entrepreneurship & 2018 & Green care \\
\hline $\begin{array}{l}\text { Study/ } \\
\text { Material }\end{array}$ & $\begin{array}{l}\text { Interview, observation at } \\
\text { the farm and café, } \\
\text { interaction at seminar, web } \\
\text { material, photos }\end{array}$ & $\begin{array}{l}\text { Interview, web material, } \\
\text { social media material, } \\
\text { photos, observation at the } \\
\text { hat factory, discussions } \\
\text { with her husband and } \\
\text { employees }\end{array}$ & $\begin{array}{l}\text { Interview, photos, web } \\
\text { material }\end{array}$ & $\begin{array}{l}\text { Two interviews, two } \\
\text { observations on the farm, } \\
\text { social media }\end{array}$ \\
& & Manufacturing & Transportation & Care \\
\hline $\begin{array}{l}\text { Business/ } \\
\text { Sector }\end{array}$ & Farming & Factory $50 \mathrm{~m}$ from home & $\begin{array}{l}\text { Coach depot and office } \\
\text { close to the home }\end{array}$ & Lives at the croft \\
\hline Place & Lives on the farm & & \\
\hline
\end{tabular}

These interviews are contrasted with the construction of innovation as a perpetual activity pursued by the creative, visionary and heroic male genius (Alsos, Ljunggren and Hytti, 2013; Andersson et al., 2012; Pecis, 2016). We understand these contrasts as 'tension points' that emerge when empirical cases collide with mainstream understandings (Flyvbjerg, Landman and Schram, 2012), which is instructive in the feminist production of transformative knowledge (Bell et al., 2020). These tension points can challenge - and potentially change - the innovation discourse to become less exclusive and excluding, and become instead more inclusive regarding how innovation can be 'walked and talked'. Often innovation was 'walked', in that our interviewees did not use the concept of innovation to describe their practices, despite describing unconventional ideas and businesses, but instead emphasised change, creativity, and experimentation. However, at times innovation was 'talked', which is emphasised in the stories.

The stories selected are based on empirical material gathered during micro-ethnography, comprising interviews, observations, visits, participation in the activities, social media and other information from the web (Bell, 2010). The stories stress alternatives to conventional understandings of innovation, namely being in the present, staying in a specific place, experimentation, contemplation, caring for others and creating reciprocal relations. When we approached the primary material, we re-read the interviews and selected five stories each. These were discussed and reflected upon, by both authors, from the selection criteria of variation in relation to non-knowing, passion and pactivity, which left us with four cases in total (see Table 1). Although the interviews were mainly conducted with women, we also purposively selected three cases where the women worked closely with a male partner and, in one case, with family. Our intention was to stress how innovation was 'walked' jointly in the mundane.

In our analysis of the four stories, we approached the interview transcript and made a draft for the story. Our two versions were then woven into the story presented in the article, with the aim of keeping the nuances and giving the reader an impression of how innovation was performed in that particular context. In the next step of the analysis, we consulted our theoretical sources of inspiration. In this way, the stories thus came first, as the article is driven by empirical insights. However, in order to follow publication conventions, the stories are presented here after the theoretical discussions.

Bornemark's discussion about pactivity and the human ability to stand in relation to non-knowing (which challenges the understanding of innovation activity as rational) spurred us on to pose the question: How is nonknowing expressed in the stories? Ahmed's conceptualisation of passio/passivity stresses the need for a profound openness in innovation processes, an openness that is neglected in the conventional male-centred innovation discourse. This impelled us to raise our second question: How are passion and openness expressed in the stories? These questions are summarised in Table 1, which links the stories with the discussion section, showing how the four stories relate to the conventional innovation discourse and how our 'pactive analysis' of the stories unfolds alternative discourses of innovation. For confidentiality considerations, we have de-identified the interviewees and have not disclosed the exact information about their location.

\section{STORIES OF INNOVATION AS PACTIVITY}

Below follow stories of innovators in rural areas about their relation to the unknown and to passion.

\section{Tea and Tore: Grounded in the Soil}

The landscape is beautiful, and the meadows are lush green as it is early summer and, in the distance, we can see the cows grazing. Tea, the multifunctional farmer we are interviewing, gives us space to take our time to embrace the surroundings, patiently awaiting the questions we are about to ask. It is as if she has all the time in the 
world, or perhaps she is used to giving urban people time and space, we muse. She tells us that she likes to invite people to the farm, following the maxim 'If we cannot "go global" (travel), we can at least invite the global world to visit us.'

Tea and Tore can be seen to practise innovation that stretches well beyond investing in technology (Automatic Milking System). On the farm they are adding a range of new activities, beyond traditional farming: keeping pigs over the summer; buying an old school (dismantled into modules and then re-assembled at their farm); converting the school into a café to host visitors from the city; arranging concerts during the summer; catering services; making breakfast boxes; selling boxes of lamb; making cheese and experimenting with artisan food; offering courses in cheese making, and welcoming classes of pupils to visit their farm to learn about farming. Tea and Tore are hence inviting and welcoming different groups of people to experience different aspects of the farm and rural life, to connect them to the soil and cycle of life. We find that their endeavours and the ongoing creative experimentations, resulting in many different activities sprouting from the farm ground, should also be considered innovative. Although these creative experimentations may not always involve new technologies, they enrich the concept of multifunctional farming, and depict innovation as a pactive social process that unfolds, which makes it possible for them to develop life on the farm and also contribute to enhancing rural development.

\section{Relation to the unknown}

Reading the transcript of the interview, we see that the story portrays a pactive life where new ideas are contemplated and sometimes acted upon and experimented with. During the interview, Tea took her time. This thoughtfulness recurs in her description of day-to-day interactions between herself and her Tore. They appear to make time for an unhurried walk now and again, where ideas can be mulled over while they wait for the right time to decide if, when and how to enact upon them. In addition, Tea repeatedly returns to the rural condition: nature, the animals and mastering a way to live in symbiosis with this condition. This implies embracing the unknown relation to life and death, and also the family history. Tea explains that a much-loved animal can suddenly be taken ill, forcing her and Tore to make a difficult decision. She describes living on the farm as being in relation to the circular way of life, where life and death cannot be separated (as ratio and intellectus have been), but having to embrace the difficulties, the uncomfortable, without becoming 'hard' and inaccessible to those living beings that surround her. For Tea, the unknown is not something to shy away from, but something she and her family must learn to cope with. In this sense, she appears to stand in relation to intellectus, the ability to 'stand still', making judgements in the heat of the moment (e.g., when something happens to an animal) and keeping her eyes open for the ambiguities of everyday life. Thus, between the lines of Tea's story lies the message: 'Life gives and life takes, you need to be humble.' In our words: grounded, to embrace the unknown with humility and live a pactive life.

\section{Passion and openness}

Passion is not explicitly expressed in Tea's story. Her tone is direct, avoiding too many adjectives. Perhaps this is because of her relation to the unknown. There is simply no need to use extra words to 'polish' some aspects of reality, but she remains grounded in the soil and conditions of rural life. Instead, passion sneaks in between the lines, in her smile when talking about her best friends - the dogs - who follow her everywhere or the joy of doing things together as a family and the pride of continuing the family practice of the farm. This includes the mundane work of packing boxes of meat together with the whole family on a Friday evening. It extends to the visitors and their questions, and how she can teach (urban) visitors to have a more complex understanding of the rural and how the urban and rural can never be separated, because they are inextricably linked. If Tea's passion is discursively restrained, her openness and directness shine through.

\section{Maya and Mark: Play it by Ear}

We wander around the workshop where Maya shows us all the tools needed to produce the fashionable hats which have brought the business she runs with her husband, Mark, to global recognition. The workshop is located in a rural area, some twenty kilometres north of one of the larger towns on the Swedish west coast. It is difficult to imagine that it is a node of fashion millinery. Chickens are strolling in the backyard, and the neighbouring house is home for Maya, Mark and their two young children. They moved here from Stockholm some five years ago and, Maya explains, 'the place and the house chose us', rather than them choosing to live in this small community.

The hats produced in the workshop are all hand-made but produced as part of a collection. This is highly unusual, according to Maya, who stresses that what is important and what interests her is the actual process of making the hats. She makes a strong point of not compromising either with the materials or the time it takes. Although the hats have gained recognition globally - among celebrities and in the big fashion houses - the innovation stressed by Maya is not only their creative designs, but also their approach to production, making collections of handmade hats. Shying away from efficient production, enjoying the handicraft of hat making, the perpetual activity of the machine is rejected in favour of the pactive production by humans. This production of hats can therefore be viewed as innovative through the design and production process of making hats, because 
these move beyond traditional conceptualisations of technological efficiency. Mark and Maya are passionate about the handicraft of making the hats, and maintaining and developing their professional millinery skills.

\section{Relation to the unknown}

Whilst Maya and Mark are innovative in broader terms than the conventional innovation discourse suggests, they have benefited greatly from being part of a business incubator at a nearby science park, where they have been given good business advice. Maya also underlines that the incubator staff learnt from working with her and her husband. At first, for example, the staff could not understand why Maya and Mark, who are very selective about who to work with, sometimes turned down stores interested in selling their hats. But for them, it is a question of aesthetics and their hats fitting into the stores, and of finding 'good people' to work with in long-term relationships; and 'we always insist on meeting them personally'. Selling as much as possible and making as much profit as possible is clearly not the priority. Instead, Maya gives voice to the kind of intellectus which Bornemark describes underpins artistic work, where the artist follows her ideas, and where these ideas are often embodied, and thus expressed through the ability to express herself through her designs and creations.

\section{Passion and openness}

Maya emphasises that business has never really been a focus for her, nor for her husband. Instead, she tells us that the decisions have always circled around being in the present and catching something in flight:

This is where I am now, and what do I need to do, in order to do the things I want to do at the moment? I mean, when we moved here from Stockholm everyone thought we were crazy moving away from the Swedish Mecca of fashion. However, this is who we are. When we are passionate about something and when it feels right, then we move along.

When we ask her to describe what feeling 'right' implies, she says that it is about being independent and free, and contrasts this with working for somebody else and being controlled. 'Following feelings' is not described as something that needs to be pondered upon, or grounded, but instead passion is presented in a way that appears to subsume both Maya and Mark in making decisions in life, and thus as guided by passion. It is almost as if following their passion means being 'seduced' by a dream and an imaginary future. Being open to feelings and impressions thus appears as a practice that permeates their activities. But their passion is also more long-term, as seen in their wishes to contribute to maintaining a production method with a heritage and to preserve the millinery profession.

\section{Beata and Her Family: Creating Community}

It is a sunny day at the beginning of June, and people are strolling by as we enjoy lunch close to the library in the small town on the east coast. Beata tells me how she decided to take over the coach company which her grandfather started. This was something that her father opposed at the time, but of which he is immensely proud today. 'Although, he never says it to me,' Beata says, smiling.

Beata explains the trajectory of the company. It was started by her grandfather, who was a farmer, but who also had time to drive the coach. The company was then taken over by her father, and her father and mother ran it together. However, after her father's retirement, Beata and her mother ran the company together for four years. 'Then I was the innovator,' Beata stresses, and points to how this gave her space to come up with new ideas for what they could do with the company.

Today, Beata and her husband own the company. It is located in a rural area on a large island off the Swedish east coast, very close to the family home and the depot. Their company offers various transportation services, including a direct line from the island to Stockholm, coach trips to different destinations in Europe, and occasional coach hire for various organisations. Previously, a 'backbone' of the company was driving the school bus on the island, which they had been doing since 1954. However, a few years ago they lost this contract under the procurement process performed by the municipality. Following this unfortunate development Beata and her husband expanded the business by buying an existing travel agency.

\section{Relation to the unknown}

During the interview, Beata seldom mentions inequality or gender structures. These come up more in passing when she reflects upon her father's hesitant reaction to her desire to take over the company. It is also in passing that she mentions how the women in the community appear to make 'more' out of their entrepreneurial endeavours than the men do. In Beata's view it is the women who are developing the rural community, because they are persistent and inventive, whilst men merely follow in old footsteps. Before wrapping up the discussion, however, Beata begins to reflect upon her older sister's achievements and efforts to change unjust sociocultural systems in Saudi Arabia. We suggest that, reading between the lines, Beata has a strong sense of her own direction, of what is right for her, as well as what is wrong. Perhaps she has been inspired by her sister and her feminist work, perhaps it comes from elsewhere, but reading between the lines of the interview, we see she makes several spot-on 
reflections about inequality and what it means to live in a gendered society. The compass that Beata appears to navigate by is undeniably related to an ability to relate to non-knowing, to a sense where she has drawn clear boundaries for what she wants to do, and she does not make a fuss about things, but holds on to her direction and pursues her wishes and dreams.

\section{Passion and openness}

For Beata and her husband, running a company in the countryside (in comparison to the town) offers calm, friendly relations and a sense of belonging together. Beata emphasises that she wants to see the coach company not as a family business, but as a business with a family feeling. This involves not only her closest family, but also the employees, neighbours, and basically anyone who passes by: 'A coach company can be so much more than a coach company, it is - kind of - a social institution. People call and just want to chat. You become a bit like the local village hairdresser.' Always available and taking the time to socialise; this is how Beata describes herself and the company. Often people just drop by the office, stopping for a cup of coffee.

It's most fun in the summer when there is so much traffic, because then we have tables outside the depot.... so when we sit there and eat lunch ... [tourists] stop [and ask]: 'Oh, is there a restaurant here?' 'No, but you can have a cup of coffee.' And then you sit and talk...

Beata explains how she becomes an ambassador for the countryside and for coach travel, and how she always tries to get people involved in all contexts. She can therefore be taken to create community through continuously inviting new relationships. Beata's passion thus lies in creating a family feeling. She is enacted upon by the people she meets and does not even try to hide this. Rather, this is part of the family feeling, where everyone is invited to put their stamp on the company and its activities (thus bringing innovation). This does not mean that Beata should be described as malleable. On the contrary, her compass is firmly set, but she does not follow strict rules or stated goals. Rather, she appears to listen to her 'inner voice', which tells her to hold on to her own dreams and wishes, despite an uncertain terrain and people who want her to move in other directions.

\section{Johanna: Slow Down and Watch the Sky}

While driving to Johanna's small croft in a rural area, we worry that this will be a difficult visit and interview, as it has been a little hard to talk to her on the phone. However, when we arrive at the croft, after driving from a larger town, past a few small communities and lastly over an open pasture, she greets us with warm hugs. The impression, after following her and participating in her workday, and a further day-long visit, is that Johanna is a woman of few words. Instead, she uses more non-verbal communication in her business, such as eye contact, touching, pointing and using images and photos. This also seems to suit her clients, who she takes on for 'daily activities' at her croft, very well. They are not very verbal either, but seem to communicate in other ways. For example, one of the clients shows us that she wants to massage our hands, using a tactile technique, when we rest after lunch. The client takes out a towel and massage oil and puts them in front of us. This makes us reflect as follows, in the field notes, after a second visit: 'It is difficult to summarise the impressions after a day which has been so little about verbal expressions, but instead about non-verbal communication and emotions, and feelings that we have had, including being welcomed, calmness, freedom of stress and being in the present. 'Green care', or providing care farming, is Johanna's innovative practice. She has literally opened up her home to take care of people with varying abilities, supporting their well-being and health through providing them with opportunities to work at a pace that suits them, in the rural environment with small-scale farming activities, such as taking care of animals and growing vegetables. As her clients are not very verbal and cannot read text, Johanna uses the innovative feature of images to support their communication. For example, she has put up a plan for the daily activities on the wall, in the form of a circle representing a clock, with images and photos of the various things that the clients are to do, and when.

\section{Relation to the unknown}

For Johanna, as a care giver, relating to the unknown is very real. Working with other people through connecting them with farming - animals and plants - and nature, much of what she does is in constant relation to the unknown. She must be attentive to her clients, which sometimes implies being 'a step ahead' of them, so that they do not, for example, open the gates to let the rabbits run free or add too much salt to the food while cooking. For Johanna, being attentive also means acting in the 'heat of the moment' and solving situations and issues that arise in, and between, the humans (and animals) on the croft. A client might be upset if the cat runs away from them, for example. Johanna being a care-giver is very much about relating to the unknown, as there is no way of knowing how each working day will unfold, and therefore no set 'protocol' to follow, even though she does, of course, have a plan. 


\section{Passion and openness}

Johanna constantly notes details in the midst of performing every activity with the clients during the day. She passionately notes the drops on an aspen leave; that a small oak in the forest has lost some of its yellowed leaves; that the needles on the larch are soft. She also photographs many of these details, as well as the activities performed by the clients. Johanna's care farming thus has 'being in the present' at its heart, and she is highly present in the moment throughout the day, seeking to induce calmness in her clients. She explains that walks in the forest are central in the care farming:

It may sound simple that we just go out and walk with the dog, but for them it is a form of training, and at the same time it's also... In the beginning I had a girl who was very, very stressed, and that walk in the forest then was to practise walking and also to focus on being here and now, in the forest, and seeing things instead of being incapable of switching off from all the issues that stress you... it is important.

Johanna is also passionate in caring for her clients, which originally grew out of her own child being neurodiverse. Johanna found that her child's wellbeing increased through living on a farm with animals and through being in a rural, calm environment, close to nature.

\section{DISCUSSION: INNOVATION BEYOND BORDERS}

The ever-increasing interest and penetration of the innovation discourse in contemporary society and its male gendering prompted us to rethink it in this article from a feminist point of view. We have challenged the conventional discourse and, in particular, the focus on newness as something that requires constant activity. Fundamental to the activity is the male construct of a rational being, driven by a need to be influential, which positions the passive Other at the border of the discourse. By approaching four stories of innovative businesses in rural areas from the notion of activity and passivity as enmeshed (pactivity) we have sought to contribute to alternative feminist discourses on innovation. Thus, we have theorised innovation beyond the conventional discursive limits, and problematise innovation as an activity pursued by active, rational, emotionally in-control wo/men in technical sectors of the economy. We suggest that a feminist interrogation of innovation discourse understands and tolerates innovations as produced by pactive people being in relation to non-knowing and by being passionate and open.

In this way we have contributed a novel aspect of feminist and gender innovation research. We have deepened the conceptual and discursive borders of innovation (Pecis and Priola, 2019; Pettersson, 2007), by applying Bornemark's and Ahmed's feminist philosophical approaches. By problematising the notion of activity, we have moved beyond the technical and rationality claims that make up conventional innovation discourse (Alsos, Ljunggren and Hytti, 2013). Through our feminist engagements with innovation the gendered innovation discourse, we have also problematised the strong links between innovation and technology. We hope our feminist investigation and engagement can be built on by other feminist scholars, by, for example, applying a similar approach to capture the enmeshment of activity and passivity in other geographical contexts. Furthermore, our study can broaden theoretical discussions on innovation by allowing more complex understandings of various versions of newness to emerge. This means that practices such as the making of policy incentives must be able to take their point of departure in more complex and alternative innovation processes, rather than prioritising male technological newness.

Inspired by Bornemark's discussion $(2018 ; 2020)$ we find that the rural men and women in our study, in various ways accept non-knowing without being paralysed. Instead, they embrace non-knowing, integrating it into their stories of their mundane pactive practices. This implies slowing down and reflecting upon what a certain innovation may entail; and reflecting and acting upon whether this particular innovation is the most important one to chase. Metaphorically speaking, this requires contemplating the surfing conditions on the beach. In different ways, the stories unfold innovation as a practice where people hold on to their compass whilst walking in an uncertain terrain. This involves allowing others to enact upon them their ideas, dreams and wishes. The stories analysed do not try to fit innovation into a predestined story of the active human being who does everything by her or himself, and where innovations come 'from within' the individual's efforts to force newness upon the world.

Tea describes pactivity as active passivity (intellectus), which consists of being reflexive, thoughtful and 'grounded'. This can be understood as a restrained activity through which she appears to 'use' passivity to ground herself. Johanna is in tune with non-knowing in her silent relation to clients and nature where she seems to be able to develop embodied relationality beyond verbal expressions. Beata seems to have a compass with a firm direction, but without following strict rules or stated goals. Her compass is thus more tuned to her 'inner voice', which tells her to stand in relation to the unknown, holding on to her dreams and wishes. Finally, Maya, stands in strong relation to an artistic intellectus through which she is able to not only make space for creativity, but to prioritise a 
Table 2. Analysis - vignettes

\begin{tabular}{|c|c|c|c|c|}
\hline Case & Tea & Maya & Beata & Johanna \\
\hline Business area & $\begin{array}{l}\text { Multifunctional farming } \\
\text { Creative experimentation }\end{array}$ & $\begin{array}{l}\text { Creative designs and } \\
\text { handmade hats (in serial } \\
\text { production) }\end{array}$ & $\begin{array}{l}\text { New transportation routes } \\
\text { Acquisition of travel } \\
\text { company }\end{array}$ & Green care \\
\hline $\begin{array}{l}\text { Relation to } \\
\text { the unknown }\end{array}$ & $\begin{array}{l}\text { Grounded to embrace the } \\
\text { unknown with humility }\end{array}$ & $\begin{array}{l}\text { Embodied, the artist's } \\
\text { creative ability to stand in } \\
\text { relation to the unknown } \\
\text { and express this through } \\
\text { design and new creations }\end{array}$ & $\begin{array}{l}\text { Listening to her inner } \\
\text { voice - quietly following } \\
\text { her compass }\end{array}$ & $\begin{array}{l}\text { Connecting herself and } \\
\text { others (clients) to nature } \\
\text { and standing in relation to } \\
\text { the unknown - the clients' } \\
\text { 'silence' }\end{array}$ \\
\hline $\begin{array}{l}\text { Passion } \\
\text { /Openness }\end{array}$ & $\begin{array}{l}\text { Discursively restrained } \\
\text { passion. Openness and } \\
\text { directness in social } \\
\text { situations. } \\
\text { Continuing the family } \\
\text { history of farming. } \\
\text { Passion for nature and } \\
\text { animals - the cycle of life }\end{array}$ & $\begin{array}{l}\text { Follow one's dreams } \\
\text { Being guided by passion } \\
\text { Maintain the production } \\
\text { method and the millinery } \\
\text { profession }\end{array}$ & $\begin{array}{l}\text { Family feeling } \\
\text { Creating situations where } \\
\text { she can be 'enacted upon' } \\
\text { - absorbing ideas from } \\
\text { these social situations }\end{array}$ & $\begin{array}{l}\text { Doing good for her clients } \\
\text { Using photography - } \\
\text { another language - and } \\
\text { showing relations through } \\
\text { it } \\
\text { Opening her home and } \\
\text { herself to be enacted upon } \\
\text { by the clients and nature. }\end{array}$ \\
\hline $\begin{array}{l}\text { Alternative } \\
\text { discourses of } \\
\text { innovation as } \\
\text { pactivity }\end{array}$ & $\begin{array}{l}\text { Grounded in the soil } \\
\text { Using 'passivity' to ground } \\
\text { herself } \\
\text { Restrained activity - } \\
\text { requires contemplation } \\
\text { Making space for } \\
\text { reflexivity }\end{array}$ & $\begin{array}{l}\text { Play it by ear } \\
\text { Sensibility towards own } \\
\text { feelings, ideas and } \\
\text { following emotions rather } \\
\text { than keeping them at bay }\end{array}$ & $\begin{array}{l}\text { Creating community } \\
\text { Nurturing relations, } \\
\text { company culture of family } \\
\text { feeling, inviting people to } \\
\text { take part }\end{array}$ & $\begin{array}{l}\text { Slow down and watch } \\
\text { the sky } \\
\text { Connected to nature } \\
\text { Embodied, aesthetic and } \\
\text { sensory communication }\end{array}$ \\
\hline
\end{tabular}

creativity which is not conditioned by ratio(nal) measures. All four stories thus describe the enmeshment of activity and passivity - pactivity - and how it unfolds in different ways (see Table 2).

Following Ahmed's discussion, the concept of passivity is closely related to passion and to being enacted upon by the other. We find that when such enactment offers no peace, humans may engage in more innovative practices. Again, we find that all four women share stories which disclose invitations to others where the relationship cannot be predefined. They also, in different ways, pay attention to how existing pieces (ideas, materials, knowledge, etc.) can be joined together in new innovations. Borrowing from the conventional innovation discourse, this has required them to be courageous, to be able to let go and to - metaphorically - be swept away by a wave.

From the stories we learn about having the courage to invite (new or deeper) relationships with others, but also the courage to be in relation to the other and to death, as well as the courage to be in relation to one's own feelings and territory. In this way, Tea describes her passion for the animals and the cycle of nature and family, a kind of passion which helps her to ground herself in the community. Johanna's passion is to be in the present in and through her care farming. In contrast, Maya describes the passion of following her feelings, letting them give material shape to her and her husband's ideas through their design. For Beata, passion is related to the extended family - to creating an atmosphere where people can be close to each other and to nurturing this family feeling beyond her biological family and the company to include the rural community.

\section{CONCLUSION}

Through our feminist intervention, our ambition has been to make innovation less contained and limited to rational, active men and technology, and thus more open. Placing innovation in relation to non-knowing and passion fills it with a new meaning. In that sense, the alternative feminist discourses on innovation evoked here grounded in the soil, play it by ear, creating community, slow down and watch the sky - can 'tilt' the status quo of the innovation discourse. These alternative discourses of innovation can flourish as one 'branch on the tree' together with previous feminist attempts to understand innovation as a social process in which everyone should be able to take an equal part (e.g., Alsos, Ljunggren and Hytti, 2013; Andersson et al., 2012; Pecis, 2016; Pettersson, 2007; Pettersson and Lindberg, 2013; Schiebinger and Schraudner, 2011). In that sense they challenge established ways of knowing innovation (Harding, 1991) and contribute to a transformative research agenda of innovation studies (Bell et al., 2020).

The mobilisation of alternative feminist discourses of innovation presents us with the hope of reclaiming the concept so that it reflects collective, caring, reciprocal relations, slowness and contemplation, and thus understands innovation as pactivity. Practising innovation then implies standing in relation to one's non-knowing, being passionate and open for enactment, envisioning innovation anew. Sometimes we may ride the wave, focused, alert 
and on the edge; at other times we play like crazy at the water's edge. But there is also time and space to relax in

the grass far away from the beach.

\section{ACKNOWLEDGEMENT}

This article benefited from insightful suggestions on an earlier draft from participants at workshop "Re-thinking Research and Innovation: How Does Gender Matter?", organized by Gabriele Griffin at Uppsala University. The funding from the Kamprad Foundation and from FORTE contributed to realizing the empirical studies. Finally, the authors appreciate our longstanding collaboration in the virtual excellence center EMBLA (emblaresearch.se).

\section{REFERENCES}

Ahmed, S. (2014). Cultural Politics of Emotion. Edinburgh: Edinburgh University Press.

Alsos, A. G., Ljunggren, E. and Hytti, U. (2013). Gender and Innovation: State of the Art and a Research Agenda. International Journal of Gender and Entrepreneurship, 5(3), 236-256. https:// doi.org/10.1108/IJGE-06-2013-0049

Andersson, S., Berglund, K., Gunnarsson, E. and Sundin, E. (eds). (2012). Promoting Innovation: Policies, practices and procedures. Stockholm: Vinnova.

Bell, E. (2010). Organizational Ethnography. Qualitative Research in Organizations and Management: An International Journal, 5(2), 216-219. https:// doi.org/10.1108/17465641011068875

Bell, E., Meriläinen, S., Taylor, S. and Tienari, J. (2020). Dangerous Knowledge: The Political, Personal, and Epistemological Promise of Feminist Research in Management and Organization Studies. International Journal of Management Reviews, 22(2), 177-192. https://doi.org/10.1111/ijmr.12221

Berglund, K., and Granat Thorslund, J. (2012). Innovative Policies? Entrepreneurship and Innovation Policy from a Gender Perspective, in S. Andersson, K. Berglund, E. Gunnarsson and E. Sundin (eds), Promoting Innovation: Policies, practices and procedures (pp. 25-46). Stockholm: Vinnova.

Blake, M. K. and Hanson, S. (2005). Rethinking Innovation: Context and Gender. Environment and Planning A, 37(4), 681-701. https://doi.org/10.1068/a3710

Bornemark, J. (2018). The Renaissance of the Immeasurable: A settlement with the pedants' world domination. [English translation] Stockholm: Volante.

Bornemark, J. (2020). Horisonten finns alltid kvar: om det bortglömda omdömet (1st ed). Stockholm: Volante.

Butler, J. (2011). Gender Trouble: Feminism and the subversion of identity. New York: Routledge. https://doi.org/10.4324/9780203824979

Calás, M. B., Smircich, L. and Bourne, K. A. (2009). Extending the Boundaries: Reframing 'Entrepreneurship as Social Change' Through Feminist Perspectives. Academy of Management Review, 34(3), 552-569. https://doi.org/10.5465/amr.2009.40633597

Davies, B. and Gannon, S. (2005). Feminism/Poststructuralism, in B. Somekh and C. Lewin (eds), Research Methods in the Social Sciences (pp. 318-325). London: SAGE.

Flyvbjerg, B., Landman, T. and Schram, S. (eds). (2012). Real Social Science: Applied phronesis. Cambridge: Cambridge University Press. https:// doi.org/10.1017/CBO9780511719912

Harding, S. (1991). Whose science? whose knowledge?: thinking from women's lives. Ithaca, N.Y.: Cornell Univ. Press

McIntyre, M. P. (2015). Queering All Aboard: Challenging the Maleness of the Leisure Boat Industry. International Journal of Entrepreneurship and Small Business, 24(1), 4-22. https:/ / doi.org/10.1504/IJESB.2015.066161

Pecis, L. (2016). Doing and Undoing Gender in Innovation: Femininities and Masculinities in Innovation Processes. Human Relations, 69(11), 2117-2140. https://doi.org/10.1177/0018726716634445

Pecis, L. and Berglund K. (2021). Hidden in the Limelight: A Feminist Engagement with Innovation Studies. Organization, June 2021. https:// doi.org/10.1177/13505084211015380

Pecis, L. and Priola, V. (2019). The 'New Industrial Man' as Unhero: Doing Postfeminist Masculinities in an Italian Pharmacological Research Centre. Gender, Work \& Organization, 26(10), 1413-1432. https://doi.org/10.1111/gwao.12359

Petterson K. (2007) Men and Male as the Norm? A gender perspective on innovation policies in Denmark, Finland and Sweden. Stockholm, SE: Nordregio.

Pettersson K. and Lindberg, M. (2013) Paradoxical Spaces of Feminist Resistance - Mapping the Margin to the Masculinist Innovation Discourse. International Journal of Gender and Entrepreneurship, 5(3), 323-341. https://doi.org/10.1108/IJGE-09-2012-0039

Schiebinger, L. and Schraudner, M. (2011). Interdisciplinary Approaches to Achieving Gendered Innovations in Science, Medicine, and Engineering. Interdisciplinary Science Reviews, 36(2), 154-167. https://doi.org/10.1179/030801811X13013181961518 
Segercrantz, B., Sveiby, K. E. and Berglund, K. (2017). A Discourse Analysis of Innovation in Academic Management Literature, in B. Godin and D. Vinck (eds), Critical Studies of Innovation: Alternative approaches to the pro-innovation bias (pp. 276-295). Cheltenham, UK: Edward Elgar Publishing Limited. https://doi.org/10.4337/9781785367229.00025

Styhre, A. (2013). A Social Theory of Innovation. Malmö: Liber.

Sveiby, K. E., Gripenberg, P. and Segercrantz, B. (eds). (2012). Challenging the Innovation Paradigm. New York: Routledge. https://doi.org/10.4324/9780203120972

Wikhamn, B. R. and Knights, D. (2013). Open Innovation, Gender and the Infiltration of Masculine Discourses. International Journal of Gender and Entrepreneurship, 5(3), 275-297. https:// doi.org/10.1108/IJGE-Sep-2012-0041

Citation: Berglund, K. and Pettersson, K. (2021). Innovation Beyond Borders: On Alternative Feminist Discourses of Innovation. Feminist Encounters: A Journal of Critical Studies in Culture and Politics, 5(2), 22. https://doi.org/10.20897/femenc/11158

Copyright (C) 2021 by Author/s and Licensed by Lectito BV, Netherlands. This is an open access article distributed under the Creative Commons Attribution License which permits unrestricted use, distribution, and reproduction in any medium, provided the original work is properly cited. 